\title{
ABSOLUTE EOSINOPHIL COUNT IN ALLERGIC RHINITIS PATIENTS OF SRIKAKULAM DISTRICT OF ANDHRA PRADESH STATE- A HOSPITAL-BASED STUDY
}

\author{
Ladi Bharati Kumari Devi'1, Bora Prasada Rao ${ }^{2}$
}

1Postgraduate Student, Department of Physiology, Government Medical College, (OLD RIMS), Srikakulam, Andhra Pradesh, India.

${ }^{2}$ Associate Professor, Department of Physiology, Government Medical College, (OLD RIMS), Srikakulam, Andhra Pradesh, India.

\begin{abstract}
BACKGROUND
Allergic Rhinitis is one of the most common chronic conditions in Srikakulam district of Andhra Pradesh which has direct impact on the quality of life. Srikakulam is the poor man's Ooty and one of the costal districts of Andhra Pradesh. The association between eosinophilia and allergic rhinitis has been known since many years. It is more common in costal AP like Srikakulam district due to agricultural lands all around, exposure of pollen grains, repeated construction of roads and buildings, pollution due to motor vehicles, soil pollution due to open field defecation, soil erosion due to deforestation etc. Srikakulam district has been chosen for the study because of its backwardness in the residuary state of Andhra Pradesh. We intended to study the absolute eosinophil count in patients suffering from allergic rhinitis at Government Medical College \& General Hospital, Srikakulam.
\end{abstract}

ABSTRACT

\section{METHODS}

This observational study was conducted among 300 cases of allergic rhinitis in the age group of 12-60 yrs. both male and female patients who attended the Department of ENT, Government Medical College \& General Hospital, Srikakulam. Both OPD and inpatients, suffering from allergic rhinitis were included in the study. We analysed and correlated blood Absolute Eosinophil Count with allergic rhinitis.

\section{RESULTS}

It was observed that absolute eosinophil count is high in patients with clinical severity score of 5 to $7 \%$. Eosinophilia was observed in moderate to severe allergic rhinitis.

\section{CONCLUSIONS}

AEC was found to be simple, non-invasive, economical, outpatient procedure. There is a need to raise the normal standard value and grading of blood AEC.

HOW TO CITE THIS ARTICLE: Devi LBK, Rao BP. Absolute eosinophil count in allergic rhinitis patients of Srikakulam district of Andhra Pradesh state- a hospital-based study. J. Evolution Med. Dent. Sci. 2019;8(20):1678-1681, DOI: 10.14260/jemds/2019/369

\section{BACKGROUND}

Allergic Rhinitis is one of the most chronic conditions in the coastal Andhra Pradesh like Srikakulam District which has an impact on the quality of life.[1] It is more common in costal AP like Srikakulam district due to agricultural lands all around and exposure of pollen grains, repeated newly construction of roads and buildings, pollution due to road traffic vehicles etc. Allergic rhinitis is seasonal \& perennial condition with an appropriate history, it is found that the symptoms like congestion, sneezing, nasal itching, rhinorrhoea (Running nose) etc.[2]

Absolute Eosinophil count $[\mathrm{AEC}]$ is a valuable test for diagnosis of Allergic Rhinitis. AEC is an easy, simple, noninvasive, reliable test, valuable and very economical, for people in the diagnosis in poor areas like Srikakulam dist. Absolute Eosinophil count is a blood test that measure the number of white blood cells called Eosinophils.[3]

'Financial or Other Competing Interest': None.

Submission 27-03-2019, Peer Review 30-04-2019,

Acceptance 07-05-2019, Published 20-05-2019.

Corresponding Author:

Dr. Bora Prasada Rao,

Associate Professor,

Department of Physiology,

Government Medical College,

(OLD RIMS), Srikakulam-532001,

Andhra Pradesh, India.

E-mail: prasadaraobora@gmail.com

DOI: $10.14260 /$ jemds $/ 2019 / 369$

\section{(c) $(1) \odot$}

Eosinophils become active when a person become exposed to the allergens like pollen, dust, animal. The diagnosis of allergic rhinitis is not usually problematic one. However, it has been found that common symptomatology of-

1. Rhinitis is nasal congestion,

2. Nasal and pharyngeal itching,

3. Sneezing,

4. Running nose (Rhinorrhoea)

5. Obstruction of air passage.

Dander, moulds spore, cockroach proteins widely spread in nature are responsible for the development of allergic rhinitis. In a person with allergic rhinitis there is increase in the blood cells like eosinophils, the condition called blood eosinophilia. All occurring in a temporal relation to allergen exposure and sometime also shows significant overlap with Non-allergic rhinitis.[4]

\section{Pathophysiology and Manifestations}

Episodic rhinorrhoea, sneezing, obstruction of nasal passages with lacrimation and pruritus of conjunctiva, nasal mucosa and oropharynx are the hallmark of Allergic Rhinitis. The nasal mucosa is pale, boggy congested conjunctiva and oedematous and pharynx is generally unremarkable, swelling of the turbinate and mucous membrane with obstruction of the sinuses, ostia and Eustachian tube precipitating secondary infection of the sinuses of middle ear respectively.[4] 
The initial interaction occurs between the allergen and intraepithelial mast cells and then proceeds to involve deeper perivenular mast cells, both of which are sensitized with specific IgE.

During the symptomatic stage the mucosa are already swollen and hyperaemic. There is enhanced adverse reactivity to the seasonal pollen as well as antigenically unrelated pollen for which there is underlying hypersensitivity due to improved penetration of allergens. Biopsy specimen of nasal mucosa shows submucosal oedema with infiltration of eosinophils along with some basophils and neutrophils. The mucosal surface fluid contains IgA that is present because of its secretory products and also IgE which is apparently arrives by Diffusion from plasma cells in proximity to the mucosal surfaces. IgE fixes to mucosal and submucosal mast cells the intensity of clinical response to inhaled allergens is quantitatively related to the naturally occurring pollen doses.[4]

In sensitive individuals, the introduction of allergen into the nose is associated with sneezing, stuffiness, discharge and fluid contain histamine, PGD2 and Leukotrienes. Thus, the mast cells of the nasal mucosa and submucosa generate and release mediators through IgE dependent reactions that are capable of producing tissue oedema and eosinophilic infiltrations.[4]

Nasal ciliary mucosa entraps the allergen particles size of $>10$ micro-mm and filters air. The outer coat of entrapped allergen particles like pollen are digested by the mucosal enzymes by lysosome of Eosinophils and there is release of protein allergens of 10000 to 40000 molecular weight.[4]

\section{Aim of The Study}

Aim is to study Absolute Eosinophil Count in patients with Allergic Rhinitis at Government general Hospital of RIMS Medical College, Srikakulam, Andhra Pradesh.

\section{Objectives of The Study}

1. To find out the AEC in allergic rhinitis patients.

2. To analyse and correlate the data on various parameters like the blood Absolute Eosinophil count with severity of the clinical score and to see the levels in patients with different symptoms and different age and sex groups of patients i.e. (12 - 20,21-30,31-40,41-50 and 51-60) and sex (Male and Female) with allergic rhinitis at Government Medical college \& General Hospital, Srikakulam.

\section{METHODS}

This observational study, was conducted on about 300 cases allergic rhinitis patients (i.e. patient with history and symptoms of clear rhinorrhoea, pale discolouration of nasal mucosa, red watery eye along with one or more symptoms like nasal congestion runny nose, or sneezing ) of age more than 12 yrs. to 60 yrs. age, both male and female those attended both OPD and IN patient Units of Department of Medicine and ENT at Government Medical College and General hospital, Srikakulam, AP state. Patients with a clinical diagnosis of allergic Rhinitis up to one week were enrolled after taking written consent from 1st October 2018 to $31^{\text {st }}$ December 2018 after prior permission was taken from institutional ethical committee of government medical college, Srikakulam.

\section{Inclusion Criteria}

Patients diagnosed with allergic Rhinitis of both male and female of 12 to 60 yrs., age.

Informed consent was obtained from patients for the study. In case of minors, the consent was obtained from their parents .

\section{Exclusion Criteria}

1. Patients with evident of causes of nasal symptoms like deviated nasal septum or any other anatomic variant of nose.

2. Patients who have already taken any antihistaminic, steroids, mast cell stabilizers, nasal corticosteroids for at least one week prior.

3. Patients who suffer from other major illness like hypertension, Diabetes.

\section{Statistical Analysis}

Statistical analysis was done by Chi-square test using SPSS for windows evaluation version 15.0 and According to age and sex distribution, $\mathrm{p}$ value less than 0.05 , was considered statistically significant.

\section{RESULTS}

Around 300 cases selected and enrolled in present study of age ranged between 12 yrs. to 60 yrs., both male and female [male 147 and female 153, total 300 cases ]. The distribution of 300 cases according to age and sex are as follow: a) 12 to 20 yrs.: $m=21, f=21, b) 21$ to 30 yrs.: $m=30, f=20, c) 31$ to 40 yrs.: $\mathrm{m}=66, \mathrm{f}=57$, d) 41 to $50: \mathrm{m}=18, \mathrm{f}=31$, e) 51 to 60 yrs.: $\mathrm{m}=12, \mathrm{f}=24$ According to age and sex distribution $\mathrm{p}$ value is 0.0406 by chi-square test and is less than 0.05 which was considered statistically significant. The prevalence of allergic Rhinitis was more in the age group of 31 to 40 years of both male and female.

The distribution of 300 cases according to severity symptom scoring and blood eosinophil count ( by direct method ) was found as mentioned below in table $3,3 \mathrm{a}, 3 \mathrm{~b}$ and $\mathrm{p}$ value of severity symptom score vs blood Absolute eosinophil counts is 0.0017 by chi-square test and was less than 0.05 which was considered statistically significant. According to this statistical analysis mentioned, there is association between absolute Eosinophil count and clinical severity of symptom which is proved statistically significant.

According to visual analogue scoring the most common symptoms was rhinorrhoea and was present in all patients $(100 \%)$, out of which only rhinorrhoea in 35 cases(11.66\%), followed by sneezing present in 265 cases $(88.33 \%)$ and nasal blockage present in 65 cases (21.66\%), ocular symptoms were present in 26 cases $(8.66 \%)$ and with bronchial asthma was 7 cases $(2.33 \%)$ patients. the details of mean blood AEC and clinical severity symptom score are mentioned in detail in table ( $4 \mathrm{a}$ ).Hence upper respiratory tract infection was the most commonly involved then other symptoms in this study and details of mean blood AEC and mean Visual analogue scoring mentioned in table ( $4 \mathrm{~b}$ ). 


\begin{tabular}{|c|c|c|}
\hline Age & Number $\mathbf{n = 3 0 0}$ & Percentage \% \\
\hline 12 to 20 & 42 & 14 \\
\hline $21-30$ & 50 & 17 \\
\hline $31-40$ & 123 & 41 \\
\hline $41-50$ & 49 & 16 \\
\hline $51-60$ & 36 & 12 \\
\hline Total & $\mathbf{3 0 0}$ & $\mathbf{1 0 0} \%$ \\
\hline \multicolumn{3}{|c|}{ Standard Deviation = 39.51793 } \\
\hline mean & 60 \\
\hline \multicolumn{2}{|c|}{ Table 1. Age Wise Distribution of Patients } \\
\hline
\end{tabular}

\begin{tabular}{|c|c|c|c|}
\hline Age & Male & Female & Total \\
\hline 12 to 20 & 21 & 21 & 42 \\
\hline $21-30$ & 30 & 20 & 50 \\
\hline $31-40$ & 66 & 57 & 123 \\
\hline $41-50$ & 18 & 31 & 49 \\
\hline $51-60$ & 12 & 24 & 36 \\
\hline Total & 147 & 153 & 300 \\
\hline Percentage $\%$ & $49 \%$ & $51 \%$ & $100 \%$ \\
\hline mean & 29.4 & 30.6 & 60 \\
\hline St. dev. & 21.46625258 & 15.37205256 & 39.51793 \\
\hline \multicolumn{4}{|c|}{ Table 2. Age and Sex Wise Distribution of Patients } \\
\hline \multicolumn{4}{|c|}{$\begin{array}{l}\text { According to age and sex distribution } \mathrm{p} \text { value is } 0.0406 \text { by } \\
\text { chi-square test and is less than } 0.05 \text { which is considered } \\
\text { statistically significant. }\end{array}$} \\
\hline
\end{tabular}

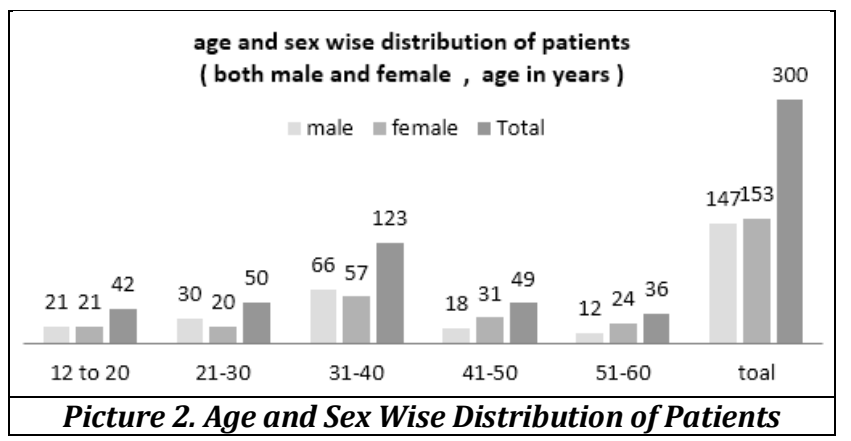

\begin{tabular}{|c|c|c|c|c|}
\hline \multirow{2}{*}{ Blood AEC out of $n=300$} & \multicolumn{4}{|c|}{ Symptom Score } \\
\hline & $\begin{array}{l}\text { Mild } \\
0-4\end{array}$ & \begin{tabular}{|c|} 
Moderate \\
$5-7$
\end{tabular} & \begin{tabular}{|c} 
Severe \\
$8-10$
\end{tabular} & $\begin{array}{c}\text { Tota } \\
1\end{array}$ \\
\hline \multicolumn{5}{|c|}{$\begin{array}{l}\text { AEC }<600 \text { cells } / \text { cumm } \\
\text { (no eosinophilia) }\end{array}$} \\
\hline$<150$ & 1 & 1 & 0 & 2 \\
\hline 151 to 300 & 1 & 2 & 0 & 3 \\
\hline 301 to 450 & 3 & 2 & 1 & 6 \\
\hline 450 to 600 & 7 & 37 & 14 & 58 \\
\hline Total & 12 & 132 & 35 & 179 \\
\hline \multicolumn{5}{|c|}{ AEC > 600 cells/cumm (blood eosinophilia ) } \\
\hline $600-1500$ (mild) & 51 & 78 & 19 & 148 \\
\hline $1500-5000$ (moderate) & 15 & 16 & 13 & 44 \\
\hline$>5000$ (severe) & 12 & 13 & 14 & 39 \\
\hline Total & 78 & 27 & 16 & 121 \\
\hline \multicolumn{5}{|c|}{$\begin{array}{l}\text { Table 3. Distribution of Severity According to Standard } \\
\text { Grading Eosinophilia Symptoms Scores }\end{array}$} \\
\hline \multicolumn{5}{|c|}{$\begin{array}{l}\text { The distribution of } 300 \text { cases according to severity symptom } \\
\text { scoring and blood eosinophil count (By direct method). } \\
\text { Distribution of patient's severity according to our grading } \\
\text { symptoms scores vs absolute eosinophil count (cells /cumm) } \\
\text { out of } N=300 \text { i.e., total number of patients) }\end{array}$} \\
\hline
\end{tabular}

\begin{tabular}{|c|c|c|c|c|c|}
\hline \multirow[t]{2}{*}{ AEC Cells/cumm } & \multirow{2}{*}{$\begin{array}{c}\text { Blood } \\
\text { AEC out } \\
\text { of } \mathbf{N}=300 \\
\text { Cases }\end{array}$} & \multicolumn{4}{|c|}{ Symptom Score } \\
\hline & & $\begin{array}{c}\text { Mild } \\
0-4\end{array}$ & $\begin{array}{c}\text { Moderat } \\
\text { e 5-7 }\end{array}$ & $\begin{array}{c}\text { Severe } \\
8-10\end{array}$ & $\begin{array}{c}\text { tot } \\
\text { al }\end{array}$ \\
\hline$<600$ & \begin{tabular}{|c|} 
no \\
eosinophil \\
ia \\
\end{tabular} & 12 & 42 & 15 & 69 \\
\hline \multirow[t]{2}{*}{$>600$} & $\begin{array}{c}\text { eosinophil } \\
\text { ia }\end{array}$ & 78 & 107 & 46 & 231 \\
\hline & Total & 90 & 149 & 61 & 300 \\
\hline \multicolumn{6}{|c|}{ Table 3a. Symptom Score: Eosinophilia vs No Eosinophilia } \\
\hline \multicolumn{6}{|c|}{$\begin{array}{l}\text { Distribution of patient's severity according to our grading } \\
\text { symptoms scores vs absolute eosinophil count (cells /cumm) } \\
\text { out of } N=300 \text { i.e., total number of patients) }\end{array}$} \\
\hline
\end{tabular}

\begin{tabular}{|c|c|c|c|c|c|}
\hline \multirow[b]{2}{*}{$\begin{array}{l}\text { Blood AEC } \\
\text { cells/ } \\
\text { cumm }\end{array}$} & \multirow{2}{*}{$\begin{array}{c}\text { Blood AEC } \\
\text { out of } \\
\mathbf{N}=\mathbf{3 0 0} \\
\text { Cases }\end{array}$} & \multicolumn{3}{|c|}{ Symptom Score } & \multirow[b]{2}{*}{ Total } \\
\hline & & $\begin{array}{c}\text { Mild } \\
0-4\end{array}$ & $\begin{array}{c}\text { Moderat } \\
\text { e 5-7 }\end{array}$ & $\begin{array}{c}\text { Severe } \\
8-10\end{array}$ & \\
\hline$<600$ & $\begin{array}{c}\text { no } \\
\text { eosinophilia }\end{array}$ & 12 & 42 & 15 & 69 \\
\hline $600-1500$ & mild & 51 & 78 & 19 & 148 \\
\hline $1500-5000$ & moderate & 15 & 16 & 13 & 44 \\
\hline$>5000$ & severe & 12 & 13 & 14 & 39 \\
\hline & Total & 90 & 149 & 61 & 300 \\
\hline
\end{tabular}

Table (3b). Distribution of Severity According to Standard Grading of Eosinophilia

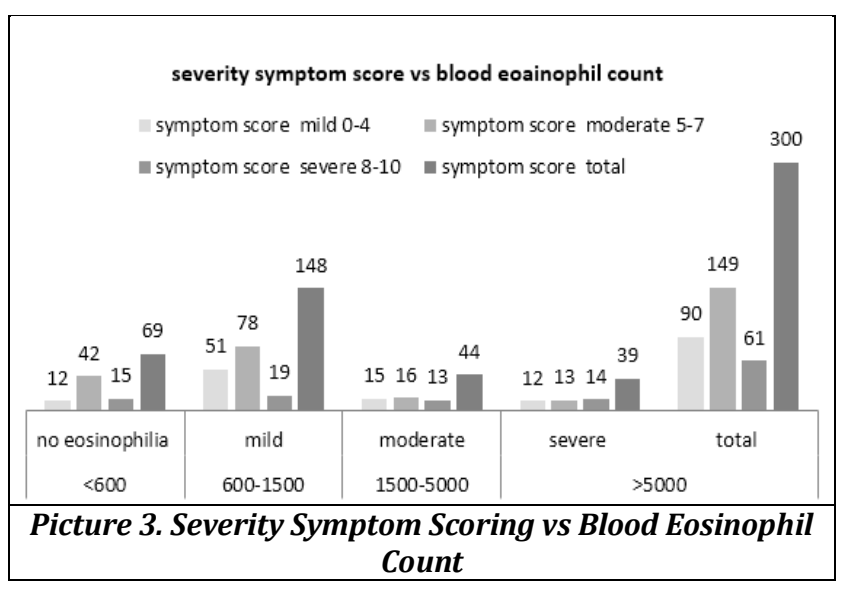

\begin{tabular}{|c|c|c|c|}
\hline & Nasal Only & $\begin{array}{c}\text { Nasal + } \\
\text { Occular }\end{array}$ & $\begin{array}{c}\text { Nasal + } \\
\text { Respiratory }\end{array}$ \\
\hline Mean blood AEC & 1198.01 & 1340.192 & 4990 \\
\hline $\begin{array}{c}\text { Mean clinical } \\
\text { severity score }\end{array}$ & 5.258 & 6.538 & 8.258 \\
\hline & $\mathrm{n}=267$ & $\mathrm{n}=26$ & $\mathrm{n}=7$ \\
\hline & $89 \%$ & $8.66 \%$ & $2.33 \%$ \\
\hline \multicolumn{3}{|c|}{$\begin{array}{c}\text { Table (4a). Mean Value of Blood AEC \& Mean Clinical } \\
\text { Severity Scoring According to Symptoms }\end{array}$} \\
\hline
\end{tabular}

\begin{tabular}{|c|c|c|}
\hline & Nasal Blockage & $\begin{array}{c}\text { Rhinorrhoea } \\
\text { \&/Sneezing }\end{array}$ \\
\hline mean AEC & 1583.738 & 1314.62 \\
\hline VAS & 6.138 & 5.645 \\
\hline & $\mathrm{n}=65$ & $\mathrm{n}=265$ \\
\hline \%age & $21.66 \%$ & $88 \%$ \\
\hline Table (4b). Mean Value of Blood AEC and Mean Visual \\
Analogue Score (VAS)
\end{tabular}


It is observed that Absolute eosinophil count is more in clinical severity score 5 to $7 \%$ and there is blood eosinophilia in moderate to severe allergic rhinitis.

According to this statistical analysis mentioned, there is association between absolute Eosinophil count and clinical severity of symptom which is proved statistically significant.

After taking complete details of history like age, sex, occupation, locality, personal history, family history, literacy etc., all patients undergone thorough clinical and general and systemic examination and recorded the vital signs. Assessment of severity of symptoms was done by visual analog scoring on a continuum scale from 0 to 10 and all are subjected for Blood AEC investigation by DIRECT method of Haemocytometry using Dunger's solution and report was recorded.

Blood Eosinophil count $>440$ cells/cumm is being considered for the presence of blood Eosinophilia. Hence, as per widely accepted criteria we had considered blood eosinophilia to be present if blood AEC $>600$ cells/cumm and degree of blood eosinophilia categorized as-
1. Mild : > $600-1500$ cells $/$ cumm
2. Moderate : > 1500 to 5000 cells /cumm
3. Severe : > 5000 cells /cumm

\section{DISCUSSION}

Eosinophils are WBC with bilobed nuclei, size 10 to 14 micron in diameter, with brick red granules in cytoplasm and nucleus bilobed spectacle shaped. The cytoplasm contains coarse red granules (Acidic stain, so red colour ie colour of Eosin). The cell membrane is very delicate, and the eosinophil found mostly in ameboid (Not phagocytic) movement in blood film. Absolute Eosinophil count estimation is done clinically by direct method by principle of hemocytometry and in this method eosinophils direct count is possible, so more accurate method of test. Sometimes, it is mandatory to determine the number of eosinophils in a particular volume of blood because it gives accurate results. In this study AEC count done by direct method, by using Dunger's solution and normal value 40 to 440 cumm of blood. [5]

The production of eosinophil is regulated by GMCSF and interleukins (IL3) and (IL5) which are produced by mast cells due to inflammation and there is increase in release of Eosinophils in blood circulation, known as blood Eosinophilia, is an important diagnostic indicator in the initial stage i.e. first one to two weeks of allergic Rhinitis symptom.[6]

Eosinophils are phagocytic, destroy organism through oxidative mechanism similar to but not identical to neutrophils.[4] Eosinophils phagocytose bacteria, fungi and inert particles, but less efficiently then neutrophils. The number of Eosinophil in blood is altered significantly in different allergic conditions like allergic rhinitis and the condition is known as blood eosinophilia.[7]

The granules of Eosinophil contain chemicals like Major Basic proteins (MBP) is a potent tissue toxin, kills adult larva and parasites also. Eosinophilic cationic proteins (ECP) is bactericidal, Larvicidal agents Eosinophil peroxidases is an enzyme that participate the inflammatory activities and Aryl sulphatase - B inactivates leukotrienes that are involved in hypersensitivity reactions. It also inactivates SRS-A (Slow reacting substances of anaphylaxis), Lysophospholipase is membrane bound enzymes that causes hydrolysis of intracellular lipoproteins and Histaminases helpful in degradation of histamine.[8]

Eosinophils count increase in blood in patients suffering from allergic Rhinitis due to exposure of abnormal exogenous or endogenous antigens leads to an immunological reaction. In these allergic conditions, eosinophils dampen host response by limiting the antigen induced release of mediators of inflammations. Eosinophils are present in large number in allergic rhinitis initially 2 wks., later enter tissue and develop tissue eosinophilia and eosinophil count in blood decreases.[9]

\section{CONCLUSIONS}

Cultivation, a common occupation all around Srikakulam district, along with rapid urbanization, air pollution due to motor vehicle, deforestation, soil erosion etc., affect the health of people of all categories. Allergic rhinitis has become a major problem. All age groups of both sexes are affected almost equally. Absolute Eosinophil Count was the preferred investigation for this study as it is an easy OPD procedure, is cost effective and gives accurate results. This helps people to get early treatment thereby minimizing complications. It also helps in guiding people to take preventive measures.

The government also has to create awareness regarding causes, preventive measures, early diagnosis and treatment for prevention of allergic rhinitis among general public. There should also be emphasis on stopping deforestation and prevention soil erosion.

\section{REFERENCES}

[1] Chatterjee CC. Chatterjee's Human physiology revised enlarged. Vol. 1. 11 th coloured edn. CBS Publishers \& Distributors Pvt Ltd., 2016.

[2] Pal GK, Pravati P. Textbook of Practical Physiology. 3rd edn. Hyderabad: Universities Press 2010.

[3] Jain AK. Manual of Practical physiology. India: Arya Publication Reprint 2017.

[4] Kasper DL, Fauci AS, Hauser SL, et al. Harrison's principles of internal medicine. 19th edn. New York: McGraw-Hill Education 2015.

[5] Dacie JV, Lewis SM, Bain BJ, et al. Dacie and Lewis Practical haematology. $10^{\text {th }}$ edn. Churchill Livingstone/Elsevier 2006.

[6] Hall JE. Guyton and Hall textbook of medical physiology. 13 $3^{\text {th }}$ edn. Philadelphia, PA: Elsevier 2016.

[7] Best CH, Taylor NB. The physiological basis of medical practice. $3^{\text {rd }}$ edn. Baltimore: The Williams and Wilkins Company, 1943.

[8] Levy MN, Berne RM, Koeppen BM, et al. Berne \& Levy Principles of physiology. $4^{\text {th }}$ edn. Philadelphia: Elsevier Mosby 2006.

[9] Ganong WF, Barrett KE. Review of medical physiology. New York: McGraw-Hill Medical Publication 2005. 